\title{
EVALUATION OF HEPATOTOXICITY IN ELDERLY WITH HIV/AIDS USING ISONIAZID
}

ARTIGO ORIGINAL

SANTANA, Claudinei Alves [1], GUTIERREZ, Eliana Battaggia [2]

SANTANA, Claudinei Alves. SANTOS, Gustavo Alves Andrade dos. Evaluation of hepatotoxicity in elderly with HIV/AIDS using isoniazid. Revista Científica Multidisciplinar Núcleo do Conhecimento. Year 05, Ed. 09, Vol. 04, pp. 98-107. September 2020. ISSN: 2448-0959, Access Link: https://www.nucleodoconhecimento.com.br/health/hepatotoxicity, DOI: 10.32749/nucleodoconhecimento.com.br/health/hepatotoxicity

\section{SUMMARY}

Introduction: The aging of the population becomes notorious from the twentieth century reaching several countries of the world. Data from the 2019 Epidemiological Bulletin of the Ministry of Health report an increase in the incidence of AIDS among elderly males in the period 2008 to 2018 of $9.7 \%$ and a $5 \%$ reduction among women. The impairment of the immune system favors the emergence of diseases considered opportunistic and Tuberculosis (TB) is the leading cause of death among individuals with AIDS. One of the measures to prevent TB/HIV co-infection in young and elderly adults, according to the World Health Organization, is treatment with the drug isoniazid, which aims to reduce the risk of illness from Mycobacterium tuberculosis and consequently the manifestation of TB. Regarding isoniazid, hepatotoxicity is a potentially serious adverse reaction that can even result in death. Objective: To evaluate the risk of hepatotoxicity to the use of isoniazid measured through laboratory test results through liver enzymes. METHOD: Descriptive and analytical retrospective cross-sectional study with elderly patients with HIV/AIDS using isoniazid in a specialized HIV/AIDS Service from 2008 to 2011. Laboratory results of hepatic transaminases (AST and ALT) and glutaryltranferase range from a secondary database at 3 specific moments 
(pre-treatment, concomitant treatment and post-treatment with isoniazid) and subjects' characteristics (age, gender, time of HIV infection) were analyzed. The data were analyzed in statistical program SPSS 20 . Result: We analyzed 12 subjects aged 60 years or older, $75 \%$ (9) men, mean age 63 years and 25\% (3) women, mean age 68 years. The subjects had an average of 15 years of HIV infection. There was an increase of $20.9 \%$ in AST, and $11.5 \%$ in the Range Gutamiltransferase concomitant with the treatment in relation to the pre-treatment values. Conclusion: Laboratory results for the use of isoniazid showed a slight hepatotoxicity elevation without the need to discontinuation of preventive treatment with isoniazid, however, follow-up by a multidisciplinary and pharmaceutical team is necessary.

Keywords: AIDS, elderly, isoniazid, hepatotoxicity, tuberculosis.

\section{INTRODUCTION}

The aging of the population becomes notorious from the 20th century, reaching several countries of the world, so epidemiological data show that individuals easily exceeded 60 years of age in the 21 st century (WHO, 2015)

Physiological changes due to aging increase the incidence and prevalence of noninfectious diseases in this population such as hypertension, diabetes, arthritis, osteoporosis. There is also the occurrence of infectious diseases such as AIDS and Tuberculosis. (RIBAS, 2014)

The comorbidities mentioned have a negative impact on the elderly because pharmacological interventions are needed as the main treatment. (RIBAS, 2014) Acquired immunodeficiency syndrome (AIDS) emerged as one of the main epidemics of infectious diseases of the 20th century (BIGGAR, 1984; COOK, 2011). AIDS, caused by HIV infection, is the result of damage mainly to cell-mediated immunity, although there is also impairment of humoral immunity. (BARASA, 2011; MOIR, 2011) Data from the 2019 Epidemiological Bulletin of the Ministry of Health report an increase in the incidence of AIDS among elderly males in the period 2008 to 2018 of $9.7 \%$ and a $5 \%$ reduction among women in the same period. (BRASIL, 2019) 
The impairment of the immune system favors the emergence of diseases considered opportunistic caused by viruses, fungi and bacteria in patients living with HIV/AIDS and Tuberculosis is the leading cause of death among individuals with AIDS (EI-SADR, 2008; STERLING, 2010; JONG, 2004)

In relation to Tuberculosis (TB), this is an important clinically important pathology, being a chronic, infectious and contagious disease, caused by Mycobacterium tuberculosis (Mtb), which can reach all age groups, but $85 \%$ of TB cases occur in adults. (SILVA, 2004).

One of the measures to prevent TB/HIV co-infection in young and elderly adults, according to the World Health Organization, is preventive treatment with isoniazid medication that aims to reduce the risk of illness by Mtb and consequently the manifestation of TB. (CONDE, 2009; HORSBURGH, 2011; DUARTE, 2007).

In Brazil, in order to reduce the risk of TB in patients living with HIV/AIDS, the Ministry of Health recommends Preventive Therapy with Isoniazid (PTI) at a dose of 5 to $10 \mathrm{mg}$ $/ \mathrm{kg} /$ day of weight up to $300 \mathrm{mg}$ for 6 consecutive months for treatment (CONDE, 2009)

Adverse Reaction to the Medicine is defined as "any harmful or unwanted effect that occurs after the administration of the drug, in doses normally used in men for prophylaxis, diagnosis or treatment of a disease. (WHO, 2002)

Regarding the use of isoniazid, hepatotoxicity, is a potentially serious adverse reaction that can result even in death if the drug is not withdrawn soon after the development of hepatitis symptoms. (COUNT, 2009; COHN, 2000; LOBUE, 2003)

Hepatotoxicity can be evaluated with asymptomatic elevation of liver enzymes such as AST (aspartate aminotransferase), ALT (alanine aminotransferase) and GGT (gammaglutamyltransferase). (CHURCHYARD, 2007; LOBUE, 2003)

With the increased incidence of HIV/AIDS in the elderly population and the risk of tuberculosis, the need for an effective assessment of the risk of hepatotoxicity in the elderly in preventive treatment with isoniazid to elderly patients living with HIV/AIDS is justified. (SILVA, 2004; LEUNG, 2011)

The pharmaceutical professional can collaborate through his technical knowledge in the assessment of the risk of hepatotoxicity as the main adverse reaction present in 
isoniazid in elderly patients with HIV/AIDS through laboratory results of liver enzymes. (SILVA, 2004; LALVANI, 2010)

This article aims to evaluate the presence of hepatotoxicity in elderly patients living with HIV/AIDS using isoniazid for tuberculosis prevention treated at a Specialized Service between 2008 and 2011 through laboratory tests of liver function enzymes ALT, AST and GGT. It is also proposed to present the characteristics of the study population in relation to age, gender, time of HIV infection.

\section{METHODOLOGY}

This is a retrospective, descriptive and analytical study in elderly adult patients with HIV/AIDS in follow-up to the Service Specializing in the care of HIV/AIDS patients of the Hospital das Clínicas of the School of Medicine of USP between 2008 and 2011. The present study was carried out with information present in an excel spreadsheet of a secondary data bank, constructed from information collected from medical records and laboratory test results, coming from previous research authorized by the Ethics and Research Committee of the Hospital das Clínicas of the Faculty of Medicine of the University of São Paulo in 2008 under number 1068/08.

Since a study was conducted based on secondary data, there was no need to apply a Free and Informed Consent Form to patients.

HIV/AIDS patients aged 60 years or older using PTI at a dose of 5 to $10 \mathrm{mg} / \mathrm{kg} / \mathrm{day}$ of weight up to $300 \mathrm{mg}$ for up to 6 months were considered eligible for the study.

The statistical analyses were performed in the statistical program SPSS Statistics, version 20, presented the descriptive analyses of the variables of interest in the form of measures of central tendency (mean, median, standard deviation, minimum and maximum) and proportions. The analysis of the association between the laboratory values of liver markers before and concomitant with the use of isoniazid was performed using the paired t-test with $95 \% \mathrm{Cl}$, being considered with statistical significance $p \leq$ $0.05 \%$. 


\section{RESULTS}

We analyzed 12 patients with a minimum age of 60 years and a maximum of 74 years, of whom $75 \%$ (9) were men (mean age of 63 years) and 25\% (3) were women (mean age 68 years). Patients had an average of 15 years of HIV infection, ranging from 7 years minimum to 21 years maximum (standard deviation 4.8 years).

Graph 1. Proportion of elderly patients with HIV/AIDS in relation to gender

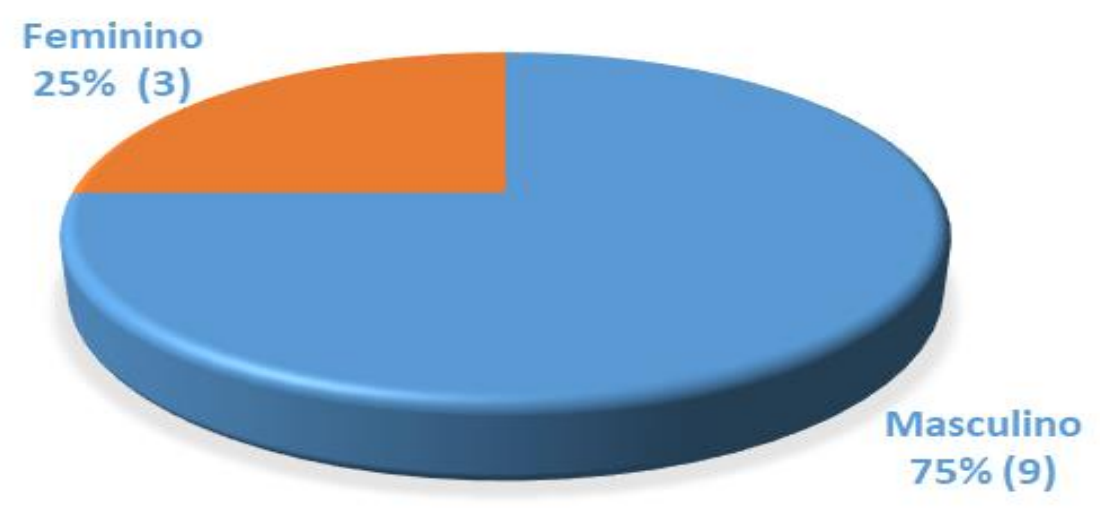

Source: author himself

Graph 2. Distribution of elderly patients with HIV/AIDS by age

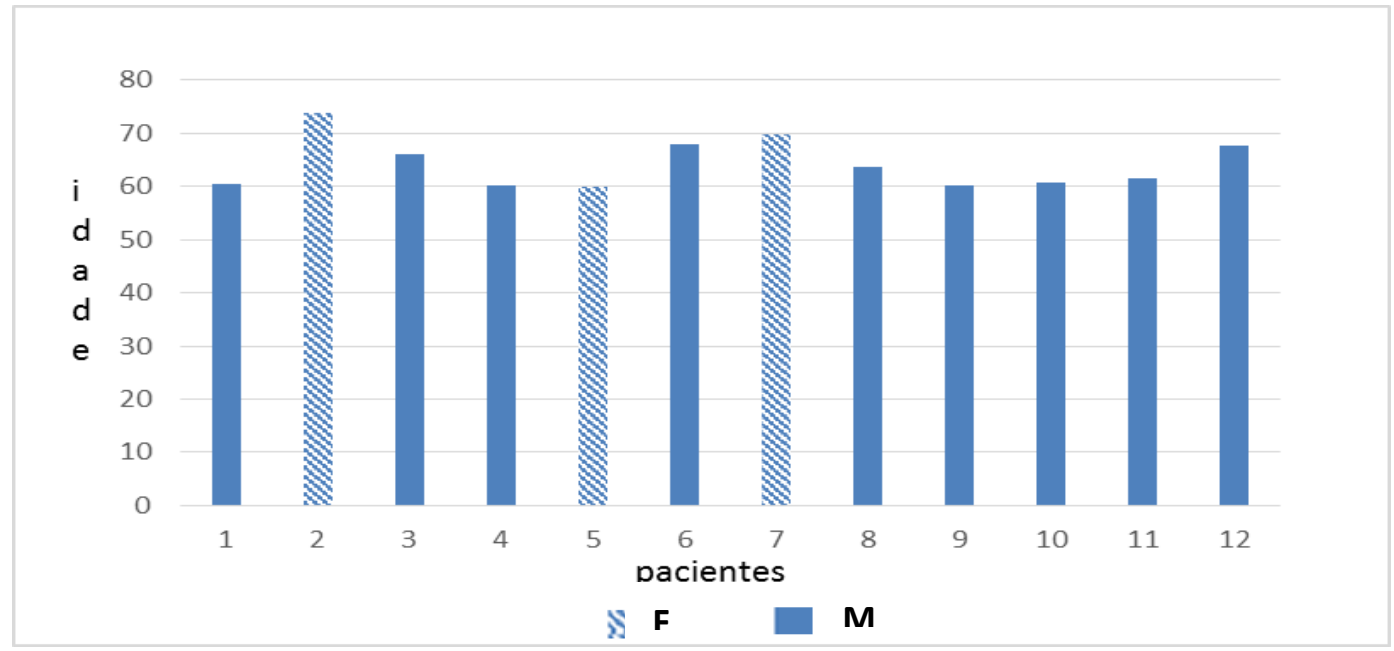

Source: author himself 
Graph 3. Distribution of elderly patients with HIV/AIDS for years of infection

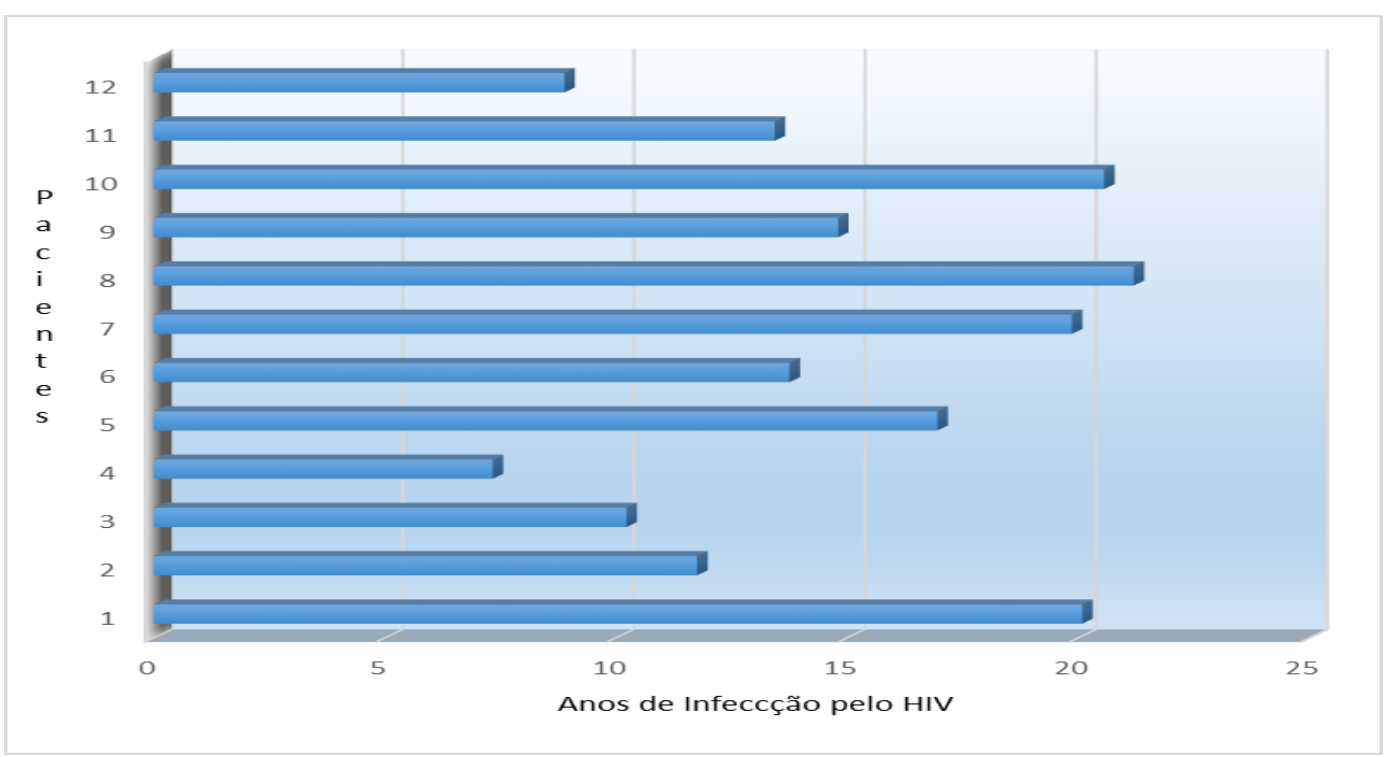

Source: author himself

Graph 4. Distribution of results of ALT, AST and GGT pre-PTI liver function tests for elderly patients with HIV/AIDS.

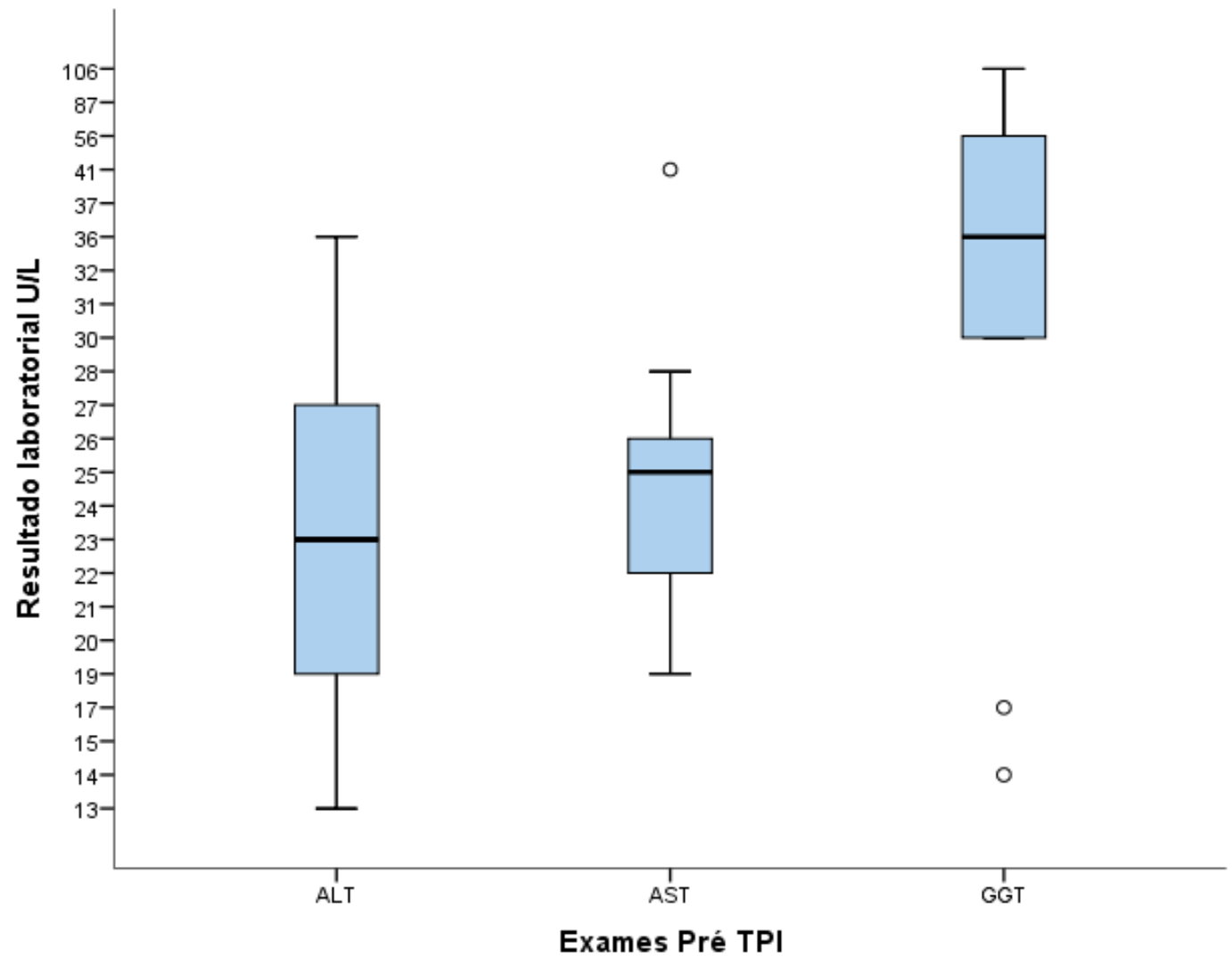

Source: author himself

RC: 61725

Disponível em: https://www.nucleodoconhecimento.com.br/health/hepatotoxicity 
Table 1: Median results of laboratory tests of liver function before, concomitant and post-ICC in elderly patients with HIV/AIDS.

\begin{tabular}{|r|c|c|c|}
\hline Period & Exams & Exams & Exams \\
\hline & AST (U/L) & ALT $(\mathrm{U} / \mathrm{L})$ & GGT $(\mathrm{U} / \mathrm{L})$ \\
\hline pre-ICC & 24,5 & 23,0 & 34,5 \\
\hline concomitant ICC & 31,0 & 22,5 & 39,0 \\
\hline post ICC & 24,5 & 22,5 & 32,0 \\
\hline
\end{tabular}

Source: author himself

There was an increase in laboratory results concomitant with the use of PTI in $20.9 \%$ of AST enzymes and $11.5 \%$ of GGT in relation to pre-treatment values.

On average, the AST result concomitant with the ICC $(M=31.0 \mathrm{U} / \mathrm{L})$ was higher than the pre-PTI result $(24.5 \mathrm{U} / \mathrm{L})$ with $\mathrm{p}=0.02$.

\section{DISCUSSION}

The elderly population increases in the world. (WHO, 2015). In the present study, only 2 female patients were 70 years of age or older. It is important to highlight that when aging there is also an increase in chronic diseases with greater use of medications to control these conditions (RIBAS, 2014). With the increase in elderly patients with HIV/AIDS, according to the Epidemiological Bulletins, there will be a greater need for follow-up by a multidisciplinary health team.

Regarding the time of HIV infection, 4 patients ( 3 men and 1 woman) had 20 years or more of HIV infection. Antiretroviral treatment presents important adverse reactions that associated with aging can lead to a worsening of quality of life for patients. (HALLAL, 2010). The use of antiretrovirals and other medicines for chronic diseases or to combat adverse reactions of antiretrovirals may favor hepatotoxicity. (FATIMA, 2009)

When using the drug isoniazid there was an increase in liver function marker enzymes (AST and GGT) when compared with pre-treatment laboratory tests characterizing 
hepatotoxicity. However, the increase was not more than 2 times the pre-treatment value that justified the suspension of use. (COUNT, 2009)

An important point is that isoniazid for the preventive treatment of tuberculosis associated with other medications may present as an additional risk factor for hepatotoxicity in elderly patients with HIV/AIDS.

In the face of aging, associated chronic diseases and the HIV/AIDS situation, elderly patients can perform an intense polypharmacy. (RAMOS, 2016) From that moment on, deletees' drug interactions, adverse reactions and intoxications may arise and the pharmacist may be intervened with this population with specific knowledge and experience in identification and intervention in Drug-Related Problems.

\section{FINAL CONSIDERATIONS}

Hepatotoxicity related to the use of isoniazid was present in elderly patients on preventive therapy confirming the theory related to this drug. However, there was no suspension of treatment, however, in view of the use of polypharmacy, it is necessary to follow the patient by the multidisciplinary team including the clinical pharmacist in the prevention of liver complications.

\section{REFERENCES}

BIGGAR, R. J. AIDS: a global problem. Cancer detection and prevention, v. 12, n. 1-6, p. 169-174, 1988

BRASIL. Ministério da Saúde. Secretaria de Vigilância em Saúde. Boletim Epidemiológico Especial Tuberculose. Brasília (DF): Ministério da Saúde; 2017a.

BRASIL. Ministério da Saúde. Boletim Epidemiológico HIV/AIDS 2019. Brasilia: Ministério da Saúde, 2019.

BARASA, Simon Situma. True story about HIV: theory of viral sequestration and reserve infection. HIV/AIDS (Auckland, NZ), v. 3, p. 125, 2011. 
CHURCHYARD, Gavin J. et al. Tuberculosis preventive therapy in the era of HIV infection: overview and research priorities. The Journal of infectious diseases, $v$. 196, n. Supplement_1, p. S52-S62, 2007.

CONDE, Marcus Barreto et al. III Diretrizes para tuberculose da Sociedade Brasileira de Pneumologia e Tisiologia. J. bras. pneumol, v. 35, n. 10, p. 1018-1048, 2009.

DE COCK, Kevin M.; JAFFE, Harold W.; CURRAN, James W. Reflections on 30 years of AIDS. Emerging infectious diseases, v. 17, n. 6, p. 1044, 2011.

DE JONG, Bouke C. et al. Clinical management of tuberculosis in the context of HIV infection. Annu. Rev. Med., v. 55, p. 283-301, 2004.

DUARTE, Raquel et al. Tratamento da tuberculose latente: Revisão das normas, 2006. Revista Portuguesa de Pneumologia (English Edition), v. 13, n. 3, p. 397418, 2007

EL-SADR, Wafaa M.; TSIOURIS, Simon J. HIV-associated tuberculosis: diagnostic and treatment challenges. In: Seminars in respiratory and critical care medicine. () Thieme Medical Publishers, 2008. p. 525-531.

DE FÁTIMA SILVA DE LIMA, Maria. Fatores de risco para hepatotoxicidade do tratamento para tuberculose em pacientes internados e coinfectados pelo HIV. 2009. Dissertação de Mestrado. Universidade Federal de Pernambuco.

HALLAL, Ronaldo et al. O acesso universal ao tratamento antirretroviral no Brasil. Tempus Actas Saude Coletiva, v. 4, n. 2, p. 53-66, 2010.

HORSBURGH JR, C. Robert; RUBIN, Eric J. Latent tuberculosis infection in the United States. New England Journal of Medicine, v. 364, n. 15, p. 1441-1448, 2011.

LALVANI, Ajit; PAREEK, Manish. A 100 year update on diagnosis of tuberculosis infection. British medical bulletin, v. 93, n. 1, p. 69-84, 2009

LEUNG, Chi Chiu et al. Treatment of latent infection with Mycobacterium tuberculosis: update 2010. 2011.

LOBUE, Philip A.; MOSER, Kathleen S. Use of isoniazid for latent tuberculosis infection in a public health clinic. American journal of respiratory and critical care medicine, v. 168, n. 4, p. 443-447, 2003.

MOIR, Susan; CHUN, Tae-Wook; FAUCl, Anthony S. Pathogenic mechanisms of HIV disease. Annual Review of Pathology: Mechanisms of Disease, v. 6, p. 223-248, 2011. 
RAMOS, Luiz Roberto et al. Polifarmácia e polimorbidade em idosos no Brasil: um desafio em saúde pública. Revista de Saúde Pública, v. 50, p. 9s, 2016.

RIBAS, Carlise; DE OLIVEIRA, Karla Renata. Perfil dos medicamentos prescritos para idosos em uma Unidade Básica de Saúde do município de ljuí-RS. Revista Brasileira de Geriatria e Gerontologia, v. 17, n. 1, p. 99-114, 2014.

SILVA, J. R. L.; BOÉCHAT, Neio. O ressurgimento da tuberculose e o impacto do estudo da imunopatogenia pulmonar. J Bras Pneumol, v. 30, n. 4, p. 478-84, 2004. STERLING, Timothy R.; PHAM, Paul A.; CHAISSON, Richard E. HIV InfectionRelated tuberculosis: Clinical manifestations and treatment. Clinical Infectious Diseases, v. 50, n. Supplement_3, p. S223-S230, 2010.

WORLD HEALTH ORGANIZATION. The Importance of Pharmacovigilance: safety monitoring of medicinal products. World Health Organization. Geneva, 2002.

WORLD HEALTH ORGANIZATION. World report on ageing and health. World Health Organization. Geneva, 2015

[1] Master in Medical Sciences - FMUSP, Specialist in Multiprofessional Oncology (IEPSL), Specialist in Educational Planning and Teaching of Higher Education (ESAB), Specialist in Hospital Pharmacy (FOC), Graduated in Biochemical Pharmacy (USJT).

[2] $\mathrm{PhD}$ in Biotechnology and Innovation in Health. (Anhanguera). Graduation in Pharmacy and Biochemistry.

Sent: July, 2020.

Approved: September, 2020. 